\title{
Global Oil Price Shocks and Effects on Economic Growth: An Econometric Investigation of Nigeria
}

\author{
${ }^{1}$ Kanu Success Ikechi, ${ }^{2}$ Nwadiubu Anthony \\ 1,2 Department of Banking and Finance, Faculty of Social and Management Sciences, Eastern \\ Palm University, Ogboko Ideato, Imo State. Nigeria
}

\begin{abstract}
This study is necessitated for the reason that global oil price shocks are bound to affect the pace of economic growth in Nigeria. Given that Nigeria is a net oil-exporting country makes it particularly vulnerable to oil price fluctuations. The study made use of secondary data covering the period from 1990 to 2019. While the Augmented Dickey-Fuller unit root test was used for preliminary analysis; ordinary least square (OLS) regression analysis was used for short-run estimates. A combination of Johansen Co-integration test, Vector Auto Regression analysis, Granger causality test, Variance Decomposition, Impulse Response tests and the ARCH/ GARCH modelling techniques were used for long run estimation All the tests helped to confirm the integrity of our models. The findings of the study indicate that, in the short run, there was sufficient evidence to show that oil price changes have a significant effect on economic growth. For the long run test, the Trace statistics and Max Eigenvalue tests point to a case of non-integration. At a ten year horizon, $71.31 \%$ of the variance in economic growth is explained by shocks; while the balance of $28.69 \%$ was accounted for by the changes in the global price of crude oil. In other words, the growth of the Nigerian economy has to do with the economy itself and to some extent, fluctuations or instability associated with the global prices of oil shocks. The ARCH/GARCH analysis indicates that there exists a first-order ARCH effect and that the GARCH in mean term was also significant. Succinctly put, the above results suggest that though erratic, there is evidence of volatility clustering of oil price on economic growth in Nigeria. The study, therefore, recommends that Nigeria splay down on the continued dominance of primary production and export and low-value addition. There is a need for a paradigm shift. Nigeria's economic growth should be driven by a diversified production structure, essentially driven by growth in manufacturing as it would increase job offer, raise productivity and incomes. Otherwise, the Nigerian economy will remain trepid, fragile and susceptible to shocks emanating from global oil price fluctuations. Poverty is likely to persist in Nigeria without a robust manufacturing sector where innovation and technology would improve value addition and raise productivity. Lastly, since an average economy is cyclical, whence the Nigerian economy can pull through the present economic recession occasioned by the Coronavirus pandemic, she must learn to save for the rainy day. Nigeria should draw lessons from history and from past mistakes in order to avert the vagaries associated with oil price volatilities and consequent budget alignment and re-alignments.
\end{abstract}

Keywords: Economic growth, Oil price shock, Net-oil exporter, OPEC, Crude oil, VAR-model

\section{Introduction}

According to the International Monetary Fund (2005) as cited by Dada (2011), oil price fluctuations impact real economic activity and pose a challenge to policymakers globally. An increase in oil price tends to have a contradictory shorter impact on global demand and growth. It is argued that higher oil prices raise inflation, with the magnitude depending in part on the extent of labour market flexibility (wage - cost-push inflation) and the producers' ability to pass 
on cost increases to consumers. Over time, the impact of rising oil prices on economic activity and inflation also depends on policy responses and supply-side effects.

Crude oil price increased on the average from US\$24.36 per barrel in 2002 to US50.59 per barrel in 2005. This upward trend in the price of crude oil in recent years reached a record nominal high of US $\$ 109.45$ in mid-2012 and a recorded a sharp drop to the US $\$ 69.78$ a barrel in 2018 and is still going down in 2019. This has generated increasing concerns about its macroeconomic implications for many countries. As it were, Nigeria is highly vulnerable to fluctuations in the international oil market despite being the 14th largest oil producer in the world. This is due to the fragile nature of the Nigerian macroeconomics and the heavy dependence on crude oil proceeds.

Nigeria is presently going through an economic recession partly brought about by the Coronavirus pandemic and a slump in the global price of oil, its' primary export product.

This study is motivated by the fact that Nigeria relies heavily on crude oil export revenues; representing about 90.0 per cent of total earnings and on an average of 70.0 per cent of government revenues in annual budgets. The distortion in the price of crude oil is bound to affect the pace of economic growth in Nigeria.

A trend of oil price fluctuations for the period under review is given in figure1below:

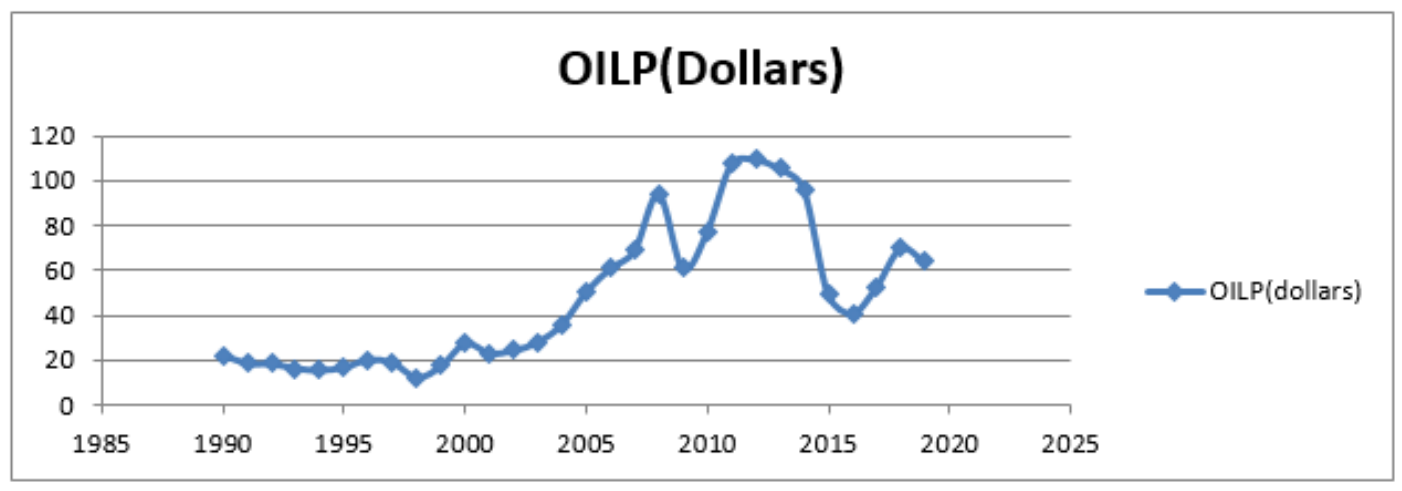

Source: OPEC Statistical Bulletin (Various editions)

As evident in the figure above, the global price of oil is far from being stable. It has witnessed a boom and burst circle - from peaking between 2012 and 2013 to a sharp decline in 2015. As of 2019, it was yet to make an appreciable increase. This trend wields an enormous economic implication for the Nigerian economy. On the other hand, a movement of Nigeria's financial growth path is presented in figure 2 below:

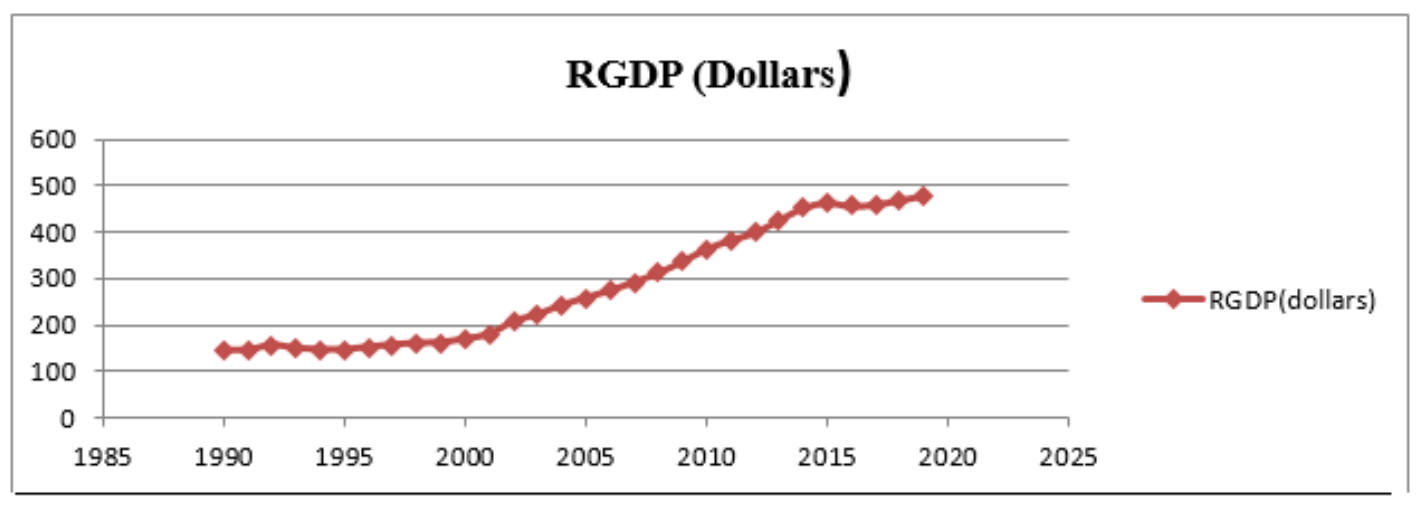

Source: World Bank (World development indicators) 
Though it looks good, it is not a sufficient and necessary condition for enhanced economic development. Dada (2011) rightly captured the above economic scenario, when he asserted that Nigeria is particularly vulnerable to oil price fluctuations due to heavy dependence on oil proceeds. Also, it is generally argued that for net exporting countries, increase in prices directly raises real income through higher export earnings. However, part of this gain would be later offset by losses from lower demand for exports generally, partially due to the economic recession suffered by trading partners.

Thus, the purpose of this study is to ascertain how oil price shocks affected economic growth in Nigeria from 1990 - 2019. The study will generate much needed empirical insight for appraising the impact of global price shock on economic growth in Nigeria. It will also proffer some remedial measures on how best to move the nation forward.

\section{Conceptual Framework}

\section{What is oil price shock?}

Oil price shocks are predominantly defined concerning price fluctuations resulting from changes in either the demand or supply side of the international oil market (Wakeford, 2006). These changes are unexpected and unpredictable and have been traditionally traced through the supply-side disruption.

\subsubsection{Identified Causes of Crude Oil Price Shocks}

According to Boheman and Mexen(2015), during the Iranian Revolution in November 1978, the world experienced second significant oil price shock resulting in an increase of the crude oil price from 13 to 35 USD per barrel (IFS, 2015) between 1978 and 1980. Shortly after the revolution, the turmoil amplified as the Iran-Iraq War began in September 1980, causing the oil price to peak (Yan, 2012). It was only in 1986 that the oil price stabilized to levels seen before the Iranian revolution (IFS, 2015).

A third substantial oil price shock was triggered by the Asian financial crisis in 1997, causing a decrease in the global oil demand. The decreased demand caused the crude oil prices globally fall from 23 USD per barrel in Q4 1996, to 12 USD per barrel in Q4 1998 (IFS, 2015). Nevertheless, the world economy recovered once again and crude oil was trading at approximately 24 USD per barrel at the end of 1999.

After 1999, the economy flourished until mid-2008, when the oil price reached its historic high at 115 USD per barrel (IFS, 2015). As the financial crisis hit the world economy later that same year, the price plummeted to 44 USD per barrel at the beginning of 2009, resulting in the fastest crash in oil price history (Kutlu, 2015).

It took approximately four years for the economies around the world to recover from this economic recession, resulting in the world crude oil price reaching 112 USD per barrel by 2012 (IFS, 2015). Nevertheless, the oil demand decreased during this time, mainly due to the strengthening of dollar currency and weak economic growth in Asian and European nations. Hence, the world market was slowly being flooded with an excessive oil supply (Yan, 2012).

In the middle of 2014, the world market experienced yet another oil price shock as prices fell from 106 to 51 USD per barrel at the beginning of 2015 (IFS, 2015). This downward trend continued as OPEC announced that they were not going to cut production, in order not to decrease their market share. As of 2019, the world market average price for crude oil stood at about 60.05 USD per barrel, and its future remains uncertain.

Other developments that contributed to the decline in oil prices during the periods of 2014 to 2015 include the significant shift in the policy objectives of OPEC, certain spillovers from geopolitical risks, and the significant appreciation of the United States currency (Attia 2017). 
The plummeting of crude oil price in 2020 can be attributed to the decline or lack of demand, owing to the outbreak of the Covid-19 virus. The pandemic caused the global shut down of operations, thereby affecting logistics and the possibility for crude oil to be physically delivered. (Nairamerics, 2020)

\subsubsection{Influential Factors Behind Oil Price Fluctuations}

According to Bohemam and Mexen (2015), when imbalances in global oil supply and demand occur, the price fluctuates. In the following section, influential primary factors that directly or indirectly create imbalances in supply and demand are as follows:

\subsubsection{Direct Effects}

According to Zhan (2008), as quoted by Bohemam and Mexen (2015), the world's production capacity following fundamental economics is defined such that an increased oil supply leads to a lowering of price. An interesting aspect related to oil is that its supply is limited to a certain degree, as it is a non- renewable resource. Since the beginning of the 1990s until 2008, no new substantial oil fields were found, and no development within transportation and refining occurred. Consequently, during this period, little improvements were made in the production capacity, making it inadequate compared to the pace of the world's consumption.

Nevertheless, in recent years the discovery of new extraction methods for shale oil has significantly affected the oil market. Through the use of cracking and horizontal drilling, it has become easier to extract oil from known but until recently not economically feasible reserves, which led to a substantial increase in oil supply. (Aguilera \& Roderick, 2013)

\subsubsection{The Production of OPEC}

The specified amount of oil produced by OPEC countries has been shown to impact the world's oil supply, and thus its price. The member states combined account for about $43 \%$ of the world's total supply (OPEC, 2014), and they act cohesively by producing oil according to a particular set of policies. Hence, the decisions they make inevitably steer prices in specific directions.

\subsubsection{The Global Economic Growth}

Global demand for crude oil directly affects its price, a relationship that can easily be seen by analyzing historical events. Yan (2012) describes how growth leads to an increase in demand for crude oil that may outperform the supply and result in an increase in the oil price. Again, when the world's economic growth and the oil demand stagnated, it resulted in plummeted prices (IFS, 2015). Hence, one can conclude that there exists a clear link between demand and fluctuations in international oil prices.

\subsubsection{Change of Crude Oil Inventories}

When the price of oil is low, producers are incentivized to increase their inventories to drive up the price. Subsequently, they can increase production again when the price has risen. As producers enter the market, prices may be pressed down again.

\subsubsection{Indirect Effects}

Practices in the future market

Speculations about the future also contribute to price disruptions. The future price of international oil works as a benchmark price when evaluating the current price. For this reason, the spot oil price is significantly affected by the opportunistic factors on the future market (Lombardi \& van Robays, 2011).

\subsubsection{Dollar Exchange Rate Fluctuations}

In 1974, the oil price was officially linked with the USD, meaning that most international oil trades were after that invoiced, delivered and settled in USD. Hence, fluctuation in the dollar exchange rate has a direct impact on the global oil price as well as oil policies in exporting and consuming countries (Yan, 2012).

\subsubsection{Geopolitical Turbulence}

Geopolitical risks add a risk premium to the international crude oil price, making the price higher. Numerous world's oil reserves are situated in politically troubled areas, and many of the world's key oil suppliers are regarded as turbulent countries such as Iran, Iraq, Nigeria, Venezuela and Russia. There are both direct and indirect impacts of political and social conflicts affecting the oil price (Keppler, 2008). 


\subsubsection{Organization of Petroleum Exporting Countries (OPEC)}

OPEC was founded in 1960, and today it consists of 12 member countries that are considered to be among the leading oil-exporting nations in the world. The organization was established by Iran, Iraq, Kuwait, Saudi Arabia and Venezuela. Today, it also consists of Algeria, Angola, Libya, Nigeria, Ecuador, Qatar and the United Arab Emirates (Dunsby et al., 2008). OPEC is considered to be an oil cartel even though its primary aim was to create a more stable oil market for both consumers and producers. This is accomplished by avoiding market price fluctuations by controlling a substantial share of the total crude oil supply (Dunsby et al., 2008).

\subsubsection{Oil Production}

OPEC controls $43 \%$ of the world's oil production, and it accounts for $81 \%$ of the world's proven reserves (OPEC, 2014). Additionally, 60\% of the exported oil in the world comes from OPEC's member countries. This considerable market share entails that they can influence the direction of international crude oil prices through the policies they set (Kaufmann et al., 2004).

Oil production has become a vital source of income for the OPEC economies, where large shares of their total GDP consist of revenues from their crude oil production. A reduction of these revenues would lead to a considerable decline in each country's GDP. Such is the example of Libya, where today, $39 \%$ of the GDP stems from oil production (WDI, 2015).

\subsubsection{Organizational Structure}

To create stability and to reach common goals, the cartel must form a cohesive group. OPEC's ability to influence prices is only as powerful as each member's willingness to oblige to the targeted production. Therefore, countries willing to join the organization can do so only if they are considered to be significant net-exporters of oil having similar interests to the other members', and are considered to be developing countries (OPEC, 2015).

\subsubsection{Economic Diversification in OPEC Countries}

For many years, the economic structure of the OPEC countries has, first and foremost, focused on the petroleum industry, as this is their primary source of income. Their heavy dependency on oil revenues has prevented these countries' economies from devoting both financial and intellectual capital to the development of other industries (Karl, 2005). Hence, many of the OPEC economies have failed to hedge themselves enough against the possibility of reduced demand for crude oil or a considerable decrease in price. At the moment, many OPEC economies are experiencing an economic decline because of the currently low oil price, especially Venezuela and Nigeria (Carlson, 2014).

As it were, a booming economic diversification within the OPEC countries would enable the economies to grow despite potential fluctuations in oil price.

\subsubsection{Economic Growth and Oil Price Fluctuations in Oil Exporting Countries}

Historically, there have been fluctuations in the prices of crude oil; these fluctuations have existed for more than three decades. The major downturns are caused by such factors wars, stock market crashes and recessions. Examples include, but are not limited to, the Gulf War, Iraq invasion, the crack in the stock market, the Dotcom bubble financial crisis, the Russian recession after the dissolution of the Soviet Union, and the Asian crisis. Supply shocks in places such as Saudi Arabia increased production from 1985 to 1986 (Rystad energy 2015). Crude oil is a crucial commodity for both importing and exporting nations, as it is either a vital input factor or a valuable source of income. A rise or fall in price is therefore of interest to these economies and can affect various macroeconomic variables, such as economic growth.

\subsubsection{Oil Price Shocks in Nigeria}

According to Dada (2011), oil price shocks in Nigeria are predominantly defined concerning price fluctuation resulting from changes in either the demand or supply side in the international markets. These changes are unexpected and unpredictable and have been traditionally traced to supply-side disruptions such as OPEC supply quotas, political upheavals in the oil-rich Middle East and activities of militant groups in the Niger Delta region of Nigeria. The shocks could be positive(a rise) or negative(a fall). Two issues are identified regarding the shock; first is the magnitude of the price increase which can be quantified in absolute terms or as percentage changes; second is the timing of the shock, that is the speed and persistence of the price increase. It is essential to indicate that oil price shocks are mainly unanticipated fluctuation in oil price above a certain percentage that is considered normal.

\subsection{Theoretical Foundation}


To better grasp the subject matter, we will provide an overview of the existing theoretical frameworks relating to oil production, motives, sales and pricing.

\subsubsection{Exhaustible Resource Theory}

This theory originated from the intellectual work of Hotelling (1931). According to the Exhaustible Resource Theory, oil and other exhaustible resources are only temporarily available, and their price should be treated as user cost or depletion charge, which compensates future generations for denial of access to the product. Capital Replacement Approach (CRA) is based on the principle of cost recovery, covering production and refining. At the minimum, the price is expected to be consistent with the cost of replacing capital in the production process.

\subsection{Empirical Review}

Crude oil is of great importance to the world's economy, as it is an essential source of income and input factor for many countries. Therefore it is not surprising that price fluctuations and their impact on growth have been widely studied among economists.

According to Boheman and Mexen(2015), the first strand of literature written on the subject of oil-price-GDP relationship focuses mainly on the U.S. economy. In 1983, Hamilton found that most of the post-World War II recessions in the U.S. could be explained by oil price increases. This relationship was found through Granger causality tests, proving that there was a link between the U.S. GDP and oil price. This connection was later confirmed by Burbridge and Harrison (1984), Gisser and Goodwin (1986) as well as Ferderer (1996). Mork (1989) established that an increase in the price of crude oil had a negative effect on U.S. production and that a decline in oil price showed no statistically significant results, indicating an asymmetric relationship. This was later verified by Hamilton (2003).

The second strand of literature considering the relationship between oil price movements and GDP widened the previous perspective by including evidence on other developed countries in addition to the U.S., with the majority being net importers of oil. Examples of such studies are Mork et al. (1994), Papapetrou (2001), Jiménez- Rodríguez and Sanchez (2005) and Lardic and Mignon (2006). These empirical studies included large OECD economies, and in most cases determined a negative relationship between oil price and GDP. Moreover, through the use of a multivariate vector autoregressive (VAR) analysis, Jiménez-Rodriguez and Sánchez (2005) found that oil price increases have an impact on GDP growth, whereas declines do not, thus confirming the existence of an asymmetric relationship, earlier found by Mork (1989) and Hamilton (2003).

Rentschler (2013) examined the significance of oil price volatility in many countries, including developed, developing, importing and exporting countries. These include Germany, India, Japan, the Republic of Korea, Malaysia, and the United States. Using VAR, Rentschler's paper concludes that an increase in oil price volatility can have negative consequences for the economies of both oil-exporting and importing countries. He also states that an economy that much depends on oil trade is more likely to be affected by price shocks. As for developing countries, fewer empirical studies exist. Berument, Ceylan and Dogan (2010) examined how oil price shocks affect the output growth in some net-exporting and net-importing countries in the Middle Eastern and North African (MENA) region, with the GDP figures ranging from 1952-2005. They suggest that oil price shocks have a significantly positive effect on the outputs of Algeria, Iran, Iraq, Kuwait, Libya, Oman, Qatar, Syria and the United Arab Emirates, of which the majority are OPEC countries, except Oman and Syria.

Coming closer home, similar studies on Nigeria include, among others, Adenuga et al. (2011), Chuku et al. (2010), Akpan(2009), Aliyu(2009). Olomola(2006) and Adejumo(2006). In particular, Akpan (2009) examined the asymmetric effects of price shocks on the Nigerian economy. The findings from her study indicated a strong positive relationship between positive oil price changes and real government expenditure. Besides, the impact of oil price shocks on industrial output growth was found to be marginal with the observed significant appreciation of the real exchange rate. Similar results were obtained by Olomola and Adejumo(2006) and Ayadi (2005), suggesting that price shocks tend to create the tendency for Dutch disease syndrome in Nigeria. 
Chuku et al. and Adeniyi et al. (2011), investigated oil price shocks and variations in selected macroeconomic indicators in Nigeria. Their findings coincide and suggest that oil price shocks do not account for a significant proportion of observed movements in macroeconomic aggregates.

\section{Methodology}

To realize the objective of this study and to understand the behaviour of time series data, and the econometric diagnostic procedure is adopted before a suitable model can be developed. Operationalization and analytical procedure are based on the following relationship model;

RGDP $=f(O I L P)$ .Equation 1

Where RGDP $=$ Real Gross domestic product and OILP $=$ Global price of oil

\subsection{Model Specification}

A functional model is specified for the time-series data to determine the relationship between the global price of crude oil and economic growth in Nigeria

$\triangle \mathrm{RGDP}_{\mathrm{t}}=\beta_{1}+\beta_{2} \sum_{t=1}^{n}$ OILP $+\sigma 1 \mathrm{VAR}(-1)+\mathrm{Et} \quad \ldots \ldots \ldots \ldots \ldots . . . .$. Equation 2.

Where VAR $(-1)$ is a VAR term and $E$ is an error term. The presumptive sign or apriori expectation for the models in equations 1 and 2 is that $\beta 1$ and $\beta 2>0$. The notations imply that an increase in oil prices may result in a Gross domestic increase.

The long-run effects are captured through the coefficients of the independent variable. That is, $\beta_{1}$ captures the impact while the coefficient of the VAR variable contains information on whether the past values of variables affect the current values of the variables under the study. The size and statistical significance of the coefficients of the residual correction terms measure the tendency of the variable to return to the equilibrium (Lutlepohl,2005).

\subsection{Estimation Procedure}

A VAR, as well as a VEC model, were used to ascertain the relationship between oil price shocks and economic growth and also to test the significance of the shocks on RGDP. The causal effects and significant relationships between oil price shocks and economic growth is determined by the Granger causality test. Also, a ten period and residual pattern of economic growth and oil price shocks, as well as ARCH /GARCH estimation techniques, were investigated over the years of study.

\section{Data Analysis, Results and Discussions}

When the time series data were subjected to unit root test at a $5 \%$ critical level, it was ascertained that RGDP is stationary at order 2 while OILP is stationary at order one. This is because the calculated values of the ADF test are greater than the critical values at $5 \%$ irrespective of the difference of the sign. This result suggests evidence of co-integration and possible VAR model application/estimation for a long-run relationship.

Table 1: Unit Root Test

\begin{tabular}{|l|l|l|l|l|l|}
\hline $\begin{array}{l}\text { Variabl } \\
\text { e }\end{array}$ & $\begin{array}{l}\text { t- } \\
\text { test }\end{array}$ & $\begin{array}{l}\text { Critical } \\
\text { value@ } \\
\mathbf{1 \%}\end{array}$ & $\begin{array}{l}\text { Critical } \\
\text { value@5 } \\
\text { \% }\end{array}$ & $\begin{array}{l}\text { Order of } \\
\text { integratio } \\
\mathbf{n}\end{array}$ & Prob \\
\hline OILP & $\begin{array}{l}--65 \\
\text { RGDP }\end{array}$ & -3.69 & -2.97 & $\begin{array}{l}\text { First } \\
\text { differenc } \\
\text { e }\end{array}$ & $\begin{array}{l}0.000 \\
9\end{array}$ \\
\hline-23 & -2.97 & $\begin{array}{l}-. .98 \\
\text { Second } \\
\text { differen } \\
\text { ce }\end{array}$ & $\begin{array}{l}0.000 \\
0\end{array}$ \\
\hline
\end{tabular}

Source: E-views statistical software version 7.0 


\subsection{Short Run Effect of Oil Price Shocks on Economic Growth in Nigeria}

The short-run analysis and discussions are based on equation 3 developed from table 3 parameter estimates.

RGDP $=3.41+0.580 I L P$

Equation 3.

Equation 3 shows that the estimate of global oil price shocks is positively related to RGDP. This simply means that any unit change in OILP accounts for $78 \%$ increase in RGDP correspondently in the short run.

Dependent Variable: RGDP

Method: Least Squares

Date: 09/22/20 Time: 22:46

Sample: 19902019

Included observations: 30

\begin{tabular}{lcccl}
\hline \hline Variable & Coefficient & Std. Error & t-Statistic & Prob. \\
\hline \hline C & 3.406240 & 0.217140 & 15.68683 & 0.0000 \\
OILP & 0.583883 & 0.058714 & 9.944481 & 0.0000 \\
\hline \hline R-squared & 0.779341 & Mean dependent var & 5.528321 \\
Adjusted R-squared & 0.771460 & S.D. dependent var & 0.460183 \\
S.E. of regression & 0.219994 & Akaike info criterion & -0.126090 \\
Sum squared resid & 1.355129 & Schwarz criterion & -0.032677 \\
Log-likelihood & 3.891352 & Hannan-Quinn criteria. & -0.096206 \\
F-statistic & 98.89271 & Durbin-Watson stat & 0.481938 \\
Prob(F-statistic) & 0.000000 & & & \\
\hline
\end{tabular}

Source: E-Views statistical package version 7

The above result suggests that there is sufficient evidence to show that oil price changes have a significant effect on economic growth. The overall model as shown in equation 3 is statistically significant as the probability value of F-statistics is 0.0000 which is less than $1 \%$. The Durbin Watson value 0.48 falls outside (2.0 and 4.0) standard scale, which confirms the presence of autocorrelations amongst the variables under review. The coefficient of determination $\left(R^{2}\right)$ value of 0.78 and adjusted R-square of 0.77 indicates that oil prices can explain economic growth positively by $78 \%$, while about $22 \%$ of economic growth cannot be explained as a result of some exogenous factors

\subsection{Long-Run Effect of Global Oil Price Shocks on Economic Growth.}

Table 4.3 shows that both the trace statistics and the max Eigenvalue test indicates a case of no co-integration. This result suggests that the null hypothesis of no cointegration between RGDP and OILP cannot be rejected at 5\% in Nigeria. Given the evidence that the series are non-stationary and do not co integrate, the study attests to the fact that the relationship between global oil price shocks and economic growth in Nigeria is unstable.

Table 2: Johansen Co-Integration Test

Unrestricted Cointegration Rank Test (Trace)

\begin{tabular}{|c|c|c|c|c|}
\hline $\begin{array}{l}\text { Hypothesize } \\
d \\
\text { No. of } C E(s)\end{array}$ & Eigenvalue & $\begin{array}{c}\text { Trace } \\
\text { Statistic }\end{array}$ & $\begin{array}{c}0.05 \\
\text { Critical Value }\end{array}$ & Prob.** \\
\hline Non & 0.292520 & 9.967050 & 15.49471 & 0.2833 \\
\hline At most 1 & 0.009871 & 0.277775 & 3.841466 & 0.5982 \\
\hline
\end{tabular}

Trace test indicates no co-integration at the 0.05 level Unrestricted Cointegration Rank Test (Maximum Eigenvalue) 
Kanu Success Ikechi, Nwadiubu, Anthony

Global Oil Price Shocks and Effects on Economic Growth: An Econometric Investigation of Nigeria

\begin{tabular}{|c|c|c|c|c|}
\hline $\begin{array}{l}\text { Hypothesize } \\
\text { d } \\
\text { No. of CE(s) }\end{array}$ & Eigenvalue & $\begin{array}{c}\text { Max-Eigen } \\
\text { Statistic }\end{array}$ & $\begin{array}{c}0.05 \\
\text { Critical Value }\end{array}$ & Prob.** \\
\hline None & 0.292520 & 9.689276 & 14.26460 & 0.2331 \\
\hline At most 1 & 0.009871 & 0.277775 & 3.841466 & 0.5982 \\
\hline
\end{tabular}

Source: E-views statistical software version 7

\subsection{Vector Autoregression Estimates of OILP and RGDP in Nigeria}

Date: 09/19/20 Time: 18:46

Sample (adjusted): 19922019

Included observations: 28 after adjustments

Standard errors in ( ) \& t-statistics in [ ]

\begin{tabular}{|c|c|c|}
\hline & OILP & RGDP \\
\hline $\operatorname{OILP}(-1)$ & $\begin{array}{r}0.913362 \\
(0.21373) \\
{[4.27349]}\end{array}$ & $\begin{array}{r}0.041058 \\
(0.02802) \\
{[1.46555]}\end{array}$ \\
\hline $\operatorname{OILP}(-2)$ & $\begin{array}{r}-0.295979 \\
(0.21523) \\
{[-1.37519]}\end{array}$ & $\begin{array}{r}-0.003894 \\
(0.02821) \\
{[-0.13802]}\end{array}$ \\
\hline $\operatorname{RGDP}(-1)$ & $\begin{array}{r}1.490496 \\
(1.55019) \\
{[0.96150]}\end{array}$ & $\begin{array}{r}1.290396 \\
(0.20320) \\
{[6.35034]}\end{array}$ \\
\hline RGDP(-2) & $\begin{array}{r}-1.030000 \\
(1.44927) \\
{[-0.71070]}\end{array}$ & $\begin{array}{r}-0.345490 \\
(0.18997) \\
{[-1.81863]}\end{array}$ \\
\hline $\mathrm{C}$ & $\begin{array}{r}-1.164989 \\
(0.98528) \\
{[-1.18239]}\end{array}$ & $\begin{array}{r}0.197395 \\
(0.12915) \\
{[1.52838]}\end{array}$ \\
\hline R-squared & 0.880050 & 0.995038 \\
\hline Adj. R-squared & 0.859189 & 0.994175 \\
\hline Sum sq. resids & 1.582965 & 0.027199 \\
\hline S.E. equation & 0.262344 & 0.034389 \\
\hline F-statistic & 42.18672 & 1153.014 \\
\hline Log likelihood & 0.490393 & 57.38455 \\
\hline Akaike AIC & 0.322115 & -3.741754 \\
\hline Schwarz SC & 0.560008 & -3.503860 \\
\hline Mean dependent & 3.678783 & 5.567962 \\
\hline S.D. dependent & 0.699124 & 0.450567 \\
\hline \multicolumn{3}{|c|}{ Determinant resid covariance (dof } \\
\hline \multicolumn{2}{|c|}{ Determinant resid covariance } & $4.86 \mathrm{E}-05$ \\
\hline \multicolumn{2}{|c|}{ Log likelihood } & 59.58752 \\
\hline \multicolumn{2}{|c|}{ Akaike information criterion } & -3.541965 \\
\hline \multicolumn{2}{|c|}{ Schwarz criterion } & -3.066178 \\
\hline
\end{tabular}

The vector autoregressive model extracted from table 5 above is stated thus:

RGDP $=0.91$ OILP $_{(-1)}-0.3$ ILP $_{(-2)}+$ 1.49RGDP $_{(-1)}-1.03$ RGDP $_{(-2)} \ldots \ldots . . .$. Equation 4 
The vector autoregressive model (Equation 4) deduced from above table indicates that in the previous years ( $t-1)$ economic growth is positively significant to current year RGDP as the probability of the t-ratio $(6.35)$ is greater than the rule of thumb of 2.0 points.

\subsection{Causal Effects}

Next, is a granger causality test. The essence is to ascertain causal relationships between global oil price shocks and economic growth in Nigeria. This is shown in table 6 below.

\section{Pairwise Granger Causality Tests}

Date: 09/19/20 Time: 18:50

Sample: 19902019

Lags: 2

\begin{tabular}{lrrr}
\hline \hline Null Hypothesis: & Obs & F-Statistic & Prob. \\
\hline \hline & 28 & 1.37525 & 0.2728 \\
RGDP does not Granger Cause OILP & & 1.52872 & 0.2380 \\
OILP does not Granger Cause RGDP & & & \\
\hline \hline
\end{tabular}

Source: E-views statistical package version 9.0

The outcome of the above test reveals that there is no causal relationship between global prices of oil and economic growth in Nigeria.

\subsection{Variance Decomposition for the VAR Models of OILP and RGDP}

\begin{tabular}{cccc} 
Period & S.E. & OILP & RGDP \\
\hline \hline 1 & 0.031715 & 15.14498 & 84.85502 \\
2 & 0.054682 & 23.19616 & 76.80384 \\
3 & 0.083924 & 34.94409 & 65.05591 \\
4 & 0.111149 & 37.84497 & 62.15503 \\
5 & 0.136078 & 36.78367 & 63.21633 \\
6 & 0.158742 & 34.98068 & 65.01932 \\
7 & 0.179578 & 33.33553 & 66.66447 \\
8 & 0.198559 & 31.74803 & 68.25197 \\
9 & 0.215817 & 30.17010 & 69.82990 \\
10 & 0.231565 & 28.68600 & 71.31400 \\
\hline \hline
\end{tabular}

Source: E-views statistical package version 9.0

A review of the above variance decomposition report reveals that over a four-year horizon, 62 . $16 \%$ of the variance in economic growth is explained by their shocks; while the balance of $37.84 \%$ is accounted for by the changes in the global price of crude oil. Over time, the impact of oil prices wore off and grew again, thus regaining its dominance in helping to project the scope and significance of economic growth. 
Over a ten year horizon, $71.31 \%$ of the variance in economic growth is explained by their shocks; while the balance of $28.69 \%$ is accounted for by the changes in the global price of crude oil. In other words, the growth of the Nigerian economy has to do with the economy itself and to some extent, fluctuations or instability associated with the global prices of oil shocks.

\begin{tabular}{ccc}
\hline \hline Period & OILP & RGDP \\
\hline \hline 1 & 0.267615 & 0.000000 \\
2 & 0.269633 & 0.028431 \\
3 & 0.168531 & 0.086315 \\
4 & 0.121032 & 0.105815 \\
5 & 0.126374 & 0.105547 \\
6 & 0.115582 & 0.105455 \\
7 & 0.086690 & 0.108600 \\
8 & 0.063939 & 0.107860 \\
9 & 0.053140 & 0.103378 \\
10 & 0.045570 & 0.098575 \\
\hline \hline Period & OILP & RGDP \\
\hline \hline & 0.012342 & 0.029215 \\
1 & 0.023265 & 0.037987 \\
2 & 0.042043 & 0.047807 \\
3 & 0.047055 & 0.055648 \\
4 & 0.046216 & 0.063460 \\
5 & 0.044759 & 0.068397 \\
6 & 0.043993 & 0.071512 \\
7 & 0.042033 & 0.073558 \\
8 & 0.039185 & 0.074939 \\
9 & 0.03915 \\
10 & 0.036466 & 0.075601 \\
\hline \hline
\end{tabular}

Source: E-views statistical package version 9.0

The above tables show the pattern of one standard deviation impulse response of RGDP to OILP. There was a marginal growth from the period 1 to 4 and albeit a weak increment for period 7; while it made a marginal decrease in periods 5 to 6 and periods 8 to 10 .

\section{Response Profile}

In the case of the behavioural pattern of oil price (OILP) to Real Gross Domestic Product (RGDP); impulse response analysis shows that OILP made an appreciable leap from period 1 till period 4. This nosedived continuously and steadily from periods 5 to 10.

\section{The Residuals of Real Gross Domestic Product (RGDP) and Oil Price (OILP)}

The OILP residuals did not maintain a stable trend between 1990 and 2020. It gravitated between - 3 to 2 . In 2000, it took a quantum leap, only to come crashing in 2009. It came up again in 2011 but crashed uncontrollably between 2014 and 2016. It was yet to make an appreciable increase as of 2019.

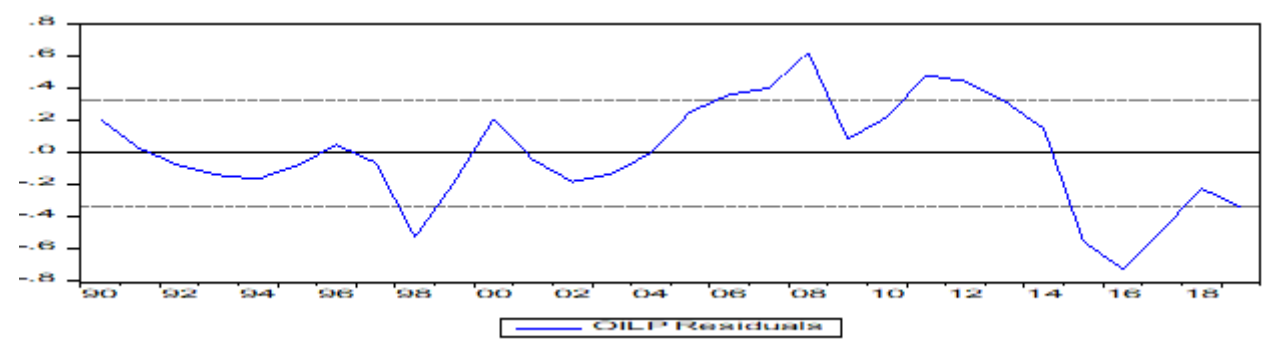

Source: E-views statistical package version 9.0 
The RGDP residuals were negative between 1990 and 1997. It became positive in 1999 and suddenly nosedived to a negative value in 2000. After which it did not maintain consistent trend overtime but took an exponential rise in 2014, only to come crashing in 2017. It was yet to make an appreciable increase as of 2019. Succinctly put, the trend has been very erratic and unpredictable. This is depicted in the graph below.

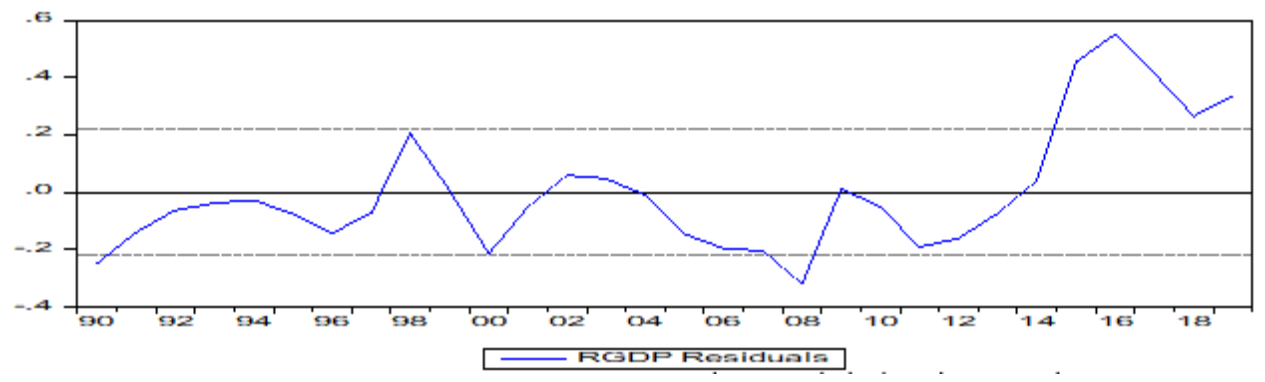

Source: E-views statistical package version 9.0

\subsection{ARCH/GARCH Volatility Modelling Approach \\ 4.9.1 Testing for ARCH Effects}

Since the LM statistic (3.67) and the t- statistics (0.05) are significant at the $10 \%$ Alpha level, $t$, we reject the null hypothesis that there are no first-order ARCH effects. In other words, there is a first-order ARCH effect.

Heteroskedasticity Test: ARCH

\begin{tabular}{lrlr}
\hline \hline F-statistic & 3.917186 & Prob. F $(1,27)$ & 0.0581 \\
Obs*R-squared & $\mathbf{3 . 6 7 4 2 7 9}$ & Prob. Chi-Square(1) & 0.0553 \\
\hline
\end{tabular}

Test Equation:

Dependent Variable: RESID^2

Method: Least Squares

Included observations: 29 after adjustments

\begin{tabular}{lrlrr}
\hline \hline \multicolumn{1}{c}{ Variable } & Coefficient & Std. Error & t-Statistic & Prob. \\
\hline \hline \multicolumn{1}{c}{ C } & 0.068762 & 0.029984 & 2.293314 & 0.0298 \\
\multicolumn{1}{c}{ RESID^2(-1) } & 0.354727 & 0.179229 & 1.979188 & $\mathbf{0 . 0 5 8 1}$ \\
\hline \hline R-squared & 0.126699 & Mean dependent var & 0.105279 \\
Adjusted R-squared & 0.094355 & S.D. dependent var & 0.133745 \\
S.E. of regression & 0.127279 & Akaike info criterion & -1.218404 \\
Sum squared resid & 0.437396 & Schwarz criterion & -1.124108 \\
Log-likelihood & 19.66686 & Hannan-Quinn criter. & -1.188871 \\
F-statistic & 3.917186 & Durbin-Watson stat & 1.878830 \\
Prob(F-statistic) & 0.058076 & & & \\
\hline
\end{tabular}

Source: Output from E-views statistical package, version 9.0

\subsubsection{ARCH MODEL OF ORDER 1- Mean Equation and Average Returns}

Dependent Variable: OILP

Method: ML - ARCH (Marquardt) - Normal distribution

Dependent Variable: OILP

Method: ML ARCH - Normal distribution (BFGS / Marquardt steps)

Presample variance: backcast (parameter $=0.7$ ) 
Kanu Success Ikechi, Nwadiubu, Anthony

Global Oil Price Shocks and Effects on Economic Growth: An Econometric Investigation of Nigeria

\begin{tabular}{|c|c|c|c|c|}
\hline Variable & Coefficient & Std. Error & z-Statistic & Prob. \\
\hline $\begin{array}{c}\mathrm{C} \\
\mathrm{RGDP}\end{array}$ & $\begin{array}{r}-3.262872 \\
1.230265\end{array}$ & $\begin{array}{l}0.721493 \\
0.132605\end{array}$ & $\begin{array}{r}-4.522386 \\
9.277679\end{array}$ & $\begin{array}{l}0.0000 \\
0.0000\end{array}$ \\
\hline \multicolumn{5}{|c|}{ Variance Equation } \\
\hline$\frac{C}{\operatorname{RESID}(-1)^{\wedge} \mathbf{2}}$ & $\begin{array}{r}0.038110 \\
\mathbf{0 . 7 3 1 2 5 9}\end{array}$ & $\begin{array}{r}0.015997 \\
\mathbf{0 . 5 6 2 0 1 2}\end{array}$ & $\begin{array}{r}2.382298 \\
\mathbf{1 . 3 0 1 1 4 3}\end{array}$ & $\begin{array}{r}0.0172 \\
\mathbf{0 . 1 9 3 2}\end{array}$ \\
\hline R-squared & 0.754869 & \multirow{6}{*}{\multicolumn{2}{|c|}{$\begin{array}{l}\text { Mean dependent var } \\
\text { S.D. dependent var } \\
\text { Akaike info criterion } \\
\text { Schwarz criterion } \\
\text { Hannan-Quinn criter. }\end{array}$}} & 3.634432 \\
\hline Adjusted R-squared & 0.746114 & & & 0.695775 \\
\hline S.E. of regression & 0.350581 & & & 0.687613 \\
\hline Sum squared resid & 3.441389 & & & 0.874440 \\
\hline Log-likelihood & -6.314200 & & & 0.747381 \\
\hline Durbin-Watson stat & 0.546928 & & & \\
\hline
\end{tabular}

Source: Output from E-views statistical package, version 9.0

The average return is -3.262872 . The variance equation gives the result of the $\mathrm{ARCH}$ model, namely, that the time-varying volatility includes a constant component $(0.038110)$ plus a component which depends on past errors (0.731259). The shaded line highlights the insignificant ARCH effects.

\subsubsection{Volatility Modeling Graph}

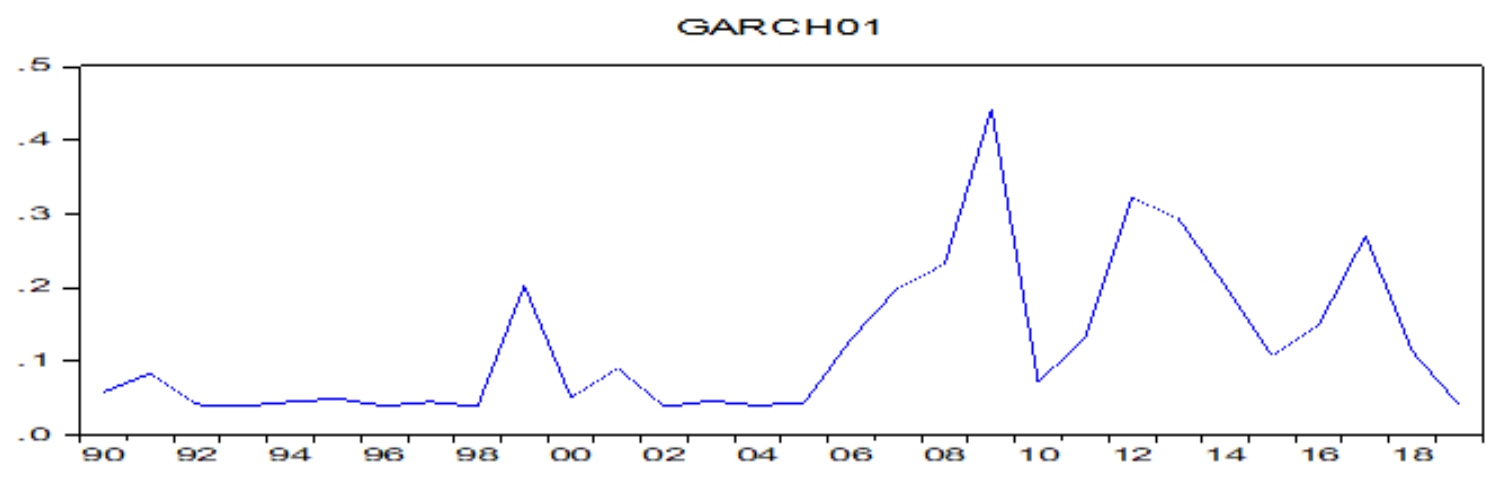

Source: Output from E-views statistical package, version 9.0

For the period under review, the global pricing of crude oil was relatively calm between 1990 and 2007 but became volatile between 2008 and 2012. It's been experiencing a circle of boom and burst seasons between 2013 and 2019.

\subsubsection{Estimating A Generalized ARCH [GARCH $(1,1)]$ Model}

Dependent Variable: OILP

Method: ML - ARCH (Marquardt) - Normal distribution

Date: 01/25/17 Time: 16:00

Sample: 19902015

Included observations: 26

Convergence achieved after 72 iterations

Presample variance: backcast (parameter $=0.7$ )

$\mathrm{GARCH}=\mathrm{C}(3)+\mathrm{C}(4)^{*} \operatorname{RESID}(-1)^{\wedge} 2+\mathrm{C}(5)^{*} \mathrm{GARCH}(-1)$

\begin{tabular}{ccccc}
\hline \hline Variable & Coefficient & Std. Error & z-Statistic & Prob. \\
\hline \hline C & -33.79649 & 7.605958 & -4.443423 & 0.0000
\end{tabular}


Kanu Success Ikechi, Nwadiubu, Anthony

Global Oil Price Shocks and Effects on Economic Growth: An Econometric Investigation of Nigeria

\begin{tabular}{ccccc} 
RGDP & 0.001298 & 0.000141 & 9.198846 & 0.0000 \\
\hline \hline Variance Equation & & \\
\hline \hline RESID(-1)^2 & 7.497510 & 9.043007 & 0.829095 & 0.4071 \\
GARCH(-1) & $\mathbf{0 . 4 8 8 2 8 3}$ & $\mathbf{0 . 2 3 6 4 5 6}$ & $\mathbf{2 . 0 6 5 0 0 6}$ & $\mathbf{0 . 0 3 8 9}$ \\
\hline \hline R-squared & 0.760117 & Mean dependent var & 48.78346 \\
Adjusted R-squared & 0.750122 & S.D. dependent var & 35.59254 \\
S.E. of regression & 17.79192 & Akaike info criterion & 8.131955 \\
Sum squared resid & 7597.255 & Schwarz criterion & 8.373897 \\
Log-likelihood & -100.7154 & Hannan-Quinn criter. & 8.201625 \\
Durbin-Watson stat & 0.912931 & & \\
\hline \hline
\end{tabular}

Source: E views statistical package, version 9

The shaded line in the E-view output shows the significance of the GARCH term. These results show that the volatility coefficients, the one in front of the ARCH effect (0.808752) and the one in front of the GARCH effect(0.488283) are both positive, but their sum is higher than one as required by theory. Since the $A R C H$ and $\mathrm{GARCH}$ effects are greater than one, then we have a case of an integrated GARCH process or I - GARCH.

\section{Estimating a Threshold or Asymmetric GARCH.}

Dependent Variable: OILP

Method: ML ARCH - Normal distribution (BFGS / Marquardt steps)

Date: 09/21/20,Time: 11:45; Sample: 1990 2019:

30 Obs.

Presample variance: backcast (parameter $=0.7$ )

$\mathrm{GARCH}=\mathrm{C}(2)+\mathrm{C}(3)^{*} \operatorname{RESID}(-1)^{\wedge} 2+\mathrm{C}(4)^{*} \operatorname{RESID}(-1)^{\wedge} 2^{*}(\operatorname{RESID}(-1)<0)$

$+$

$\mathrm{C}(5) * \mathrm{GARCH}(-1)$

\begin{tabular}{|c|c|c|c|c|}
\hline Variable & Coefficient & Std. Error & z-Statistic & Prob. \\
\hline RGDP & 0.605709 & 0.015331 & 39.50963 & 0.0000 \\
\hline \multicolumn{5}{|c|}{ Variance Equation } \\
\hline $\begin{array}{c}C \\
\operatorname{RESID}(-1)^{\wedge} 2 \\
\operatorname{RESID}(- \\
\mathbf{1})^{\wedge} \mathbf{2} *(\operatorname{RESID}(\mathbf{- 1})<\mathbf{0})\end{array}$ & $\begin{array}{l}0.071904 \\
0.826030\end{array}$ & $\begin{array}{l}0.043683 \\
0.441656\end{array}$ & $\begin{array}{l}1.646043 \\
1.870300\end{array}$ & $\begin{array}{l}0.0998 \\
0.0614\end{array}$ \\
\hline $\operatorname{GARCH}(-1)$ & $\begin{array}{r}-\mathbf{0 . 5 9 0 8 8 0} \\
-0.178225\end{array}$ & $\begin{array}{r}\mathbf{1 . 3 2 7 6 4 3} \\
0.117240\end{array}$ & $\begin{array}{r}-\mathbf{0 . 4 4 5 0 6 0} \\
-1.520178\end{array}$ & $\begin{array}{r}\mathbf{0 . 6 5 6 3} \\
0.1285\end{array}$ \\
\hline $\begin{array}{l}\text { R-squared } \\
\text { Adjusted R-squared } \\
\text { S.E. of regression } \\
\text { Sum squared resid } \\
\text { Log likelihood } \\
\text { Durbin-Watson stat }\end{array}$ & $\begin{array}{r}0.372196 \\
0.372196 \\
0.551291 \\
8.813739 \\
-10.41974 \\
0.215811\end{array}$ & \multicolumn{2}{|c|}{$\begin{array}{l}\text { Mean dependent var } \\
\text { S.D. dependent var } \\
\text { Akaike info criterion } \\
\text { Schwarz criterion } \\
\text { Hannan-Quinn criter. }\end{array}$} & $\begin{array}{l}3.634432 \\
0.695775 \\
1.027983 \\
1.261516 \\
1.102692\end{array}$ \\
\hline
\end{tabular}

Source: Output from E-views statistical package, version 9.0 
Since the coefficient on the asymmetric term is not significant, we infer that there is no evidence that positive and negative shocks of oil pricing will have different effects on the growth of Nigeria's real gross domestic product (RGDP).

\subsubsection{Estimating a GARCH - in - Mean}

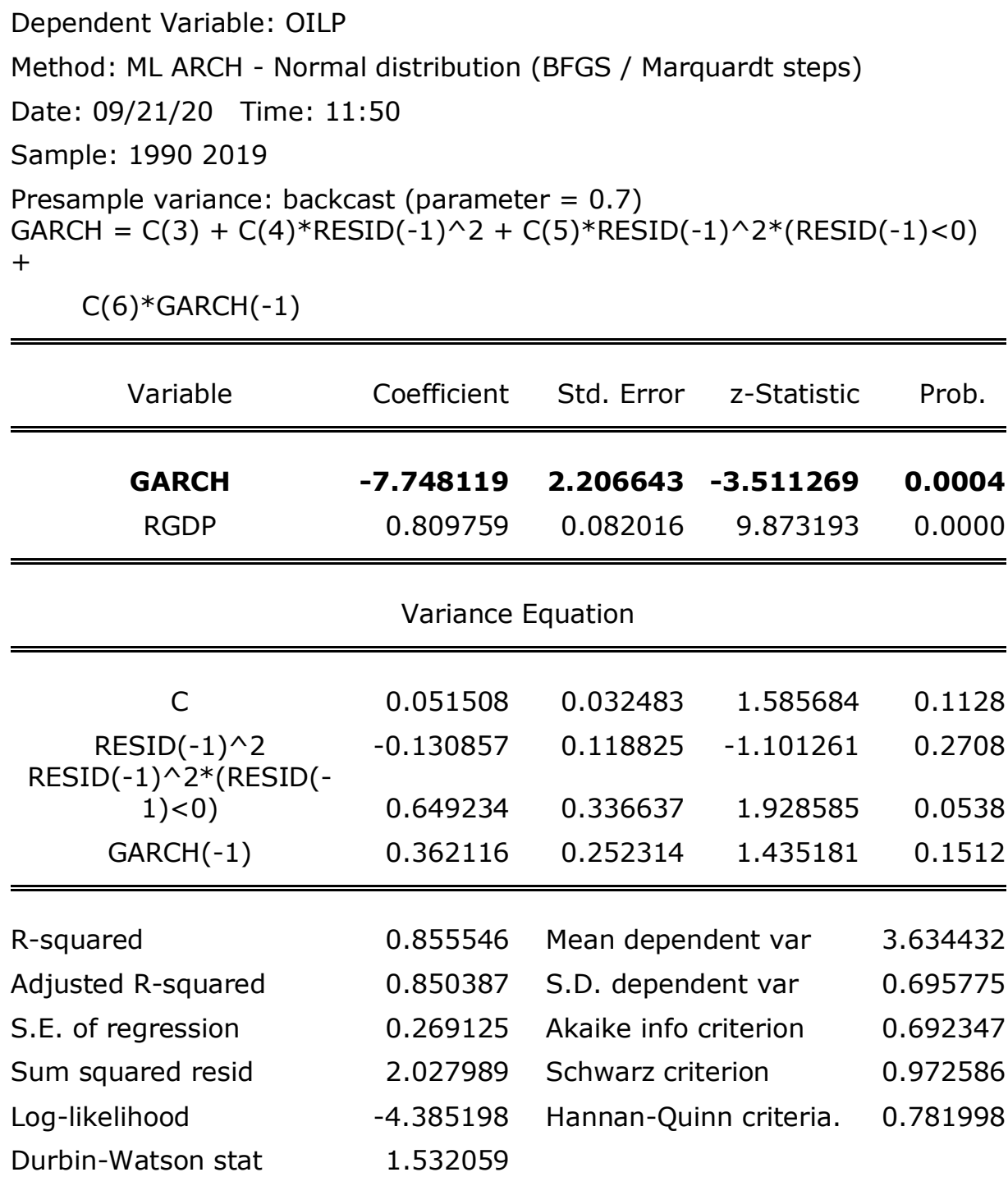

Source: E-Views statistical package, version 9.

Since the coefficient on the GARCH- In-Mean term -7.748119 is significant, we infer that there is evidence that global oil price shocks affect the growth of the real gross domestic product in Nigeria.

\subsection{Discussion of Results.}

Given the enclave nature of the Nigerian oil sector with weak linkages to other sectors of the economy; it is expedient that we discuss likes and likes. Outcomes of the study are discussed against other recent studies conducted concerning the Nigerian economy.

In our present study, it was ascertained that the LM statistics ( 3.67 ) and the t- statistics ( 0.05 ) are significant at the $10 \%$ Alpha level, $t$. We reject the null hypothesis that there are no firstorder ARCH effects. In other words, there is a first-order ARCH effect. Again, from the coefficient on the GARCH- In- Mean term $\mathbf{- 7 . 7 5}$ being significant, we infer that there is evidence that global oil price shocks affect the growth of Real Gross Domestic Product in Nigeria. The above findings 
did not corroborate the earlier works of Chuku et al. (2010) and Adeniyi (2011), where they investigated oil price shocks and variations according to the selected macroeconomic indicators in Nigeria. Their findings suggest that oil price shocks do not account for a significant proportion of observed moments in macroeconomic aggregates.

Dada (2011) investigated oil price shocks and macroeconomic aggregates in Nigeria. Findings of his study show a strong positive relationship between positive oil price changes, inflation, real government expenditures and money supply. This suggests the need for policies that focus on stabilizing the macroeconomy to withstand the vicissitudes of oil price shocks.

Olomola(2006); investigated the impact of oil price shocks on aggregate economic activity (output), inflation, the real exchange rate and money supply in Nigeria using quarterly data from 1970 to 2003. The findings showed that contrary to previous empirical finding, oil price shocks did not affect output and inflation in Nigeria significantly. However, oil price shocks were found to have a significant influence on the real exchange rate. This researcher argued that oil price shocks could give rise to wealth effects that appreciated the real exchange rate and could squeeze the tradable sector given the rise of the Dutch diseases.

From the foregoing analysis on the effects of oil price shocks on the Nigerian economy; the findings of studies are divergent. The debate remains inconclusive; thus requiring more investigations.

\section{Summary of Findings \\ This study gave rise to the following conclusions:}

- There is sufficient evidence to show that oil price changes have a significant effect on shortterm economic growth. The coefficient of determination $\left(R^{2}\right)$ value of 0.78 and adjusted $R-$ square of 0.77 indicates that oil prices explain economic growth positively by $77 \%$, while about $23 \%$ of economic growth cannot be explained as a result of some exogenous factors

- Both the trace statistics and the max Eigenvalue test indicates a case of non-cointegration. This result suggests that the null hypothesis of non-co- integration between RGDP and OILP cannot be rejected at 5\% in Nigeria.

- Given the evidence that the series are non-stationary and do not co integrate, the study attests to the fact that the relationship between global oil price shocks and economic growth in Nigeria is unstable in the long run.

- The VAR model indicates that previous years ( $t-1)$ economic growth is positively significant to current year RGDP as the probability of the t-ratio (6.35) is greater than the rule of thumb of 2.0 points.

- There is no causal relationship between global prices of oil and economic growth in Nigeria.

- Variance decomposition report reveals that over a four-year horizon, 62 . $16 \%$ of the variance in economic growth is explained by their shocks; while the balance of $37.84 \%$ is accounted for by the changes in the global price of crude oil. Over time, the impact of oil prices wore off, and growth regained dominance in helping to project the scope and significance of economic growth.

- Over a ten year horizon, $71.31 \%$ of the variance in economic growth is explained by their shocks; while the balance of $28.69 \%$ accounted by the changes in the global price of crude oil. In other words, the growth of the Nigerian economy has to do with the economy itself and to some extent, fluctuations or instability associated with the global prices of oil shocks.

- A standard deviation impulse response of RGDP to OILP indicates a marginal growth from the period 1 to 4 and albeit a weak increment for period 7; while it made a marginal decrease in periods 5 to 6 and for the periods 8 to 10 .

- In the case of the behavioural pattern of oil price (OILP) to Real Gross Domestic Product( RGDP); impulse response analysis shows that OILP made an appreciable leap from period 1 till period 4. This nosedived continuously and steadily from periods 5 to 10 .

- The OILP residuals did not maintain a stable trend between 1990 and 2020. It gravitated between - 3 to 2 . In 2000, it took a quantum leap, only to come crashing in 2009 . It came up again in 2011 but crashed uncontrollably between 2014 and 2016. It was yet to make an appreciable increase as of 2019.

- The RGDP residuals were negative between 1990 and 1997. It became positive in 1999 and suddenly nosedived to a negative value in 2000. After which it did not maintain consistent trend overtime but took an exponential rise in 2014, only to come crashing in 2017. Succinctly put, the trend has been very erratic and unpredictable 
- The ARCH/ GARCH volatility modelling techniques indicate that the LM statistic( 3.67$)$ and the t- statistics ( 0.05) are significant at $10 \%$ Alpha level, $t$, we reject the null hypothesis that there are no first-order ARCH effects. In other words, there is a first-order ARCH effect.

- For the period under review, the global pricing of crude oil was relatively calm between 1990 and 2007 but became volatile between 2008 and 2012. It's been experiencing a circle of boom and burst seasons between 2013 and 2019.

- The ARCH and GARCH effects are both positive and greater than one ( This ought not to be according to the decision rule), thus, we have a case of an" integrated GARCH process or an IGARCH

- Since the coefficient on the asymmetric term is not significant, we infer that there is no evidence that positive and negative shocks of oil pricing will affect the pace of economic growth in Nigeria.

- The coefficient on the GARCH- In- Mean term -7.75 is significant; we infer that there is evidence that global oil price shocks affect the growth of Real Gross Domestic Product in Nigeria.

\section{Conclusion}

Based on the results of empirical analysis, it was ascertained that in the short run, there was sufficient evidence to indicate that oil price changes have a significant effect on economic growth. The same was not the case in the long run as both the trace statistics and the max Eigenvalue test indicate a case of no co-integration. This result suggests that the null hypothesis of no cointegration between RGDP and OILP cannot be rejected at $5 \%$ in Nigeria. Thus, the study attests to the fact that the relationship between global oil price shocks and economic growth in Nigeria is unstable in the long run. The VAR model indicates that the previous year's economic growth is positively significant to current year RGDP as the probability of the t-ratio (4.68) is greater than the rule of thumb of 2 . While the OILP residuals did not maintain a stable trend between 1990 and 2020. It gravitated between - 3 to 2. In 2000, it took a quantum leap, only to come crashing in 2009. It came up again in 2011 but crashed uncontrollably between 2014 and 2016. It was yet to make an appreciable increase as of 2019. The RGDP residuals were negative between 1990 and 1997. It became positive in 1999 and suddenly nosedived to a negative value in 2000. After which it did not maintain consistent trend overtime but took an exponential rise in 2014, only to come crashing in 2017. It was yet to make an appreciable increase as of 2019. Succinctly put, the trend has been very erratic and unpredictable. Lastly, in the course of this study, we pursued the entire ARCH/ GARCH variations. The results indicate that, there is a first-order ARCH effect significant at $10 \%$ Alpha level and that the coefficient on the GARCH in mean term was significant. Succinctly put, the above results indicate that though erratic, there is evidence of volatility clustering of oil price shocks on the economic growth of Nigeria. The fluctuation in oil price is an eye-opener for the Nigerian economy to consider the need for diversification. The country must explore other avenues to make it's economy viable rather than depending solely on oil commodity.

\subsection{Recommendations}

It is clear from the foregoing analysis that, the Nigerian nation needs to turn to the production of other commodities that are high in demand elsewhere in the world. The federal government of Nigeria should sustain the ongoing amnesty program to the Niger Delta militants as it is helping to curb the arbitrary case of crude oil theft/ bunkering, disruption of exploration and the free flow/processing of oil. Other changes that should be put in place include enhanced optimal production of crude oil for export subject to production quota from the oil cartel-OPEC. It is pertinent that as the government plans, budgets and implements expenditure decisions; the leaders should be mindful of Nigerian overall level of revenue accruals, set priorities for its allocation and to ensure quality within each of the expenditure categories. These calls for fiscal planning with a primary objective to forecast and to take cognizance of resource constraints and the linkages it spurs within the broader economy. There is a need for a paradigm shift. The study, therefore, recommends that Nigeria plays down on the continued dominance of primary production and export and low-value addition. Nigeria's economic growth should be achieved through a diversified production structure nearly driven by growth in manufacturing, thus creating job opportunities, rise in productivity and incomes. Otherwise, the Nigerian economy will remain trepid, fragile and susceptible to negative shocks. Poverty is likely to persist in Nigeria without a robust manufacturing sector where innovation and technology would improve 
value addition and raise productivity. Lastly, since an average economy is cyclical, whence the Nigerian economy can pull through the present economic recession occasioned by the coronavirus pandemic. Nigeria should learn to save for the rainy day to avert the vagaries associated with oil price fluctuations and consequent budget alignment and re-alignment. The issue of establishing a sovereign wealth fund should be revisited. Nigeria must draw lessons from history and past mistakes.

\section{References}

- Adeniyi O., A. Oyinlola and O. Omisakin (2011). "Oil price shocks and economic growth in Nigeria: Are thresholds important, OPEC Energy preview.Vol 35: 308-333. DOI: 10. 11 11/j.1753 $0237.2011 .00192 . x$ Crossref

- Adenuga, A. O., M. J ., Hilili, and O. Evbuomwan (2011). "Oil price pass-through into Inflation: Empirical evidence from Nigeria ". Paper presented at the $16^{\text {th }}$ Annual Conference of the African Econometric Society on Economic modelling for Africa, 13-15 July, Kenya School of Monetary Studies, Nairobi

- Akpan, E O. (2009) ." Oil price shocks and Nigeria Macroeconomy ". A paper presented At the Annual conference of CSAE, Economic Development in Africa, $22^{\text {nd }}-24$ th March Oxford University.

- Amano R. and S Van Norden (1998) "Oil Prices and Exchange Rates" Review of International Economics, January 1998.

- Anashasy, E.A (2005). "Evidence on the role of oil prices in Venezuela's economic performance: 1950-2001" Working Paper, University of Washington.

- Aliyu, S.U.R. (2009). Oil price shocks and the macroeconomy of Nigeria: A non-linear approach. MPRA Paper No. 18726.

- Ayadi, O.F. (2005). Oil Price fluctuations and the Nigerian economy. OPEC Review, Sept. 199-217. Crossref

- Bachmeier, L (2008). Monetary and the transmission of oil shocks. Journal of Macroeconomics, 30, 1738-1755. Crossref

- Barsky, R. B., and L. Kilian. (2004). Oil and the Macroeconomy since the 1970 s. NBER Working 10855. Retrieved from http://www.nber.org/papers/w10855 Crossref

- Bartleet, M. and R. Gounder(2007). "Oil price shocks and Economic Growth: Evidence for New Zealand of Economist Annual Conference, $27^{\text {th }}$ June 2007. Quality assured paper.

- Bernanke, B.S., M. Gertler, and M.W. Watson (19970. Systematic Monetary policy and the Effects of oil price Shocks. Brookings Papers on Economic Activity, 1:91-148 Crossref

- Bohi, Douglas R. (1991). Energy price shocks and macroeconomic performance. Washington, D.C.: Resources for the Future.

- Blanchard, O.J and J. Gali (2007). "the macroeconomic effects of Oil Price Shocks: Why are the 2000s different from the 1970Sş, MIT Department of Economics Working Paper No.0721. Crossref

- Boheman Hanna and Maxum Joseph (2015) "Oil price Shocks effect on economic growth: OPEC Verus Non-OPEC economy http://swopec.hhs.se/lucomp/sponsor.jpg

- Bruno, M. and Sachs (1982. "Input price shocks and the slowdown in Economic growth: the Case of U.K. manufacturing", Review of Economic Studies,49, 679-705. Crossref

- Central Bank of Nigeria statistical Bulletin various issues.

- CBN, (2009). Statistical Bulletin, (special Edition) Central Bank of Nigeria, Abuja

- Chuku, C.A., E. Effiong and N. sam (2010). Oil price distortions and their long and short-run impacts on the Nigerian economy. Paper presented at the $51^{\text {st }}$ annual conference of the Nigerian Economic Society (NES). $25^{\text {th }}$ to $27^{\text {th }}$ October 2010 at Nicon Luxury Hotels, Abuja

- Chuku, C.A., U. Akpan, E. Effiong and N. sam (2011). Oil price shocks and the dynamic of currents account balances in Nigeria. OPEC Energy Review, 35(2) 199-139. Crossref

- Corden, M.W. (1984). "booming sector and Dutch disease Economics: Survey and Consolidation, Oxford Economic papers 36, 359-380. Crossref

- Dahl, C.A., and M. Yucel. (1991). "testing Alternative Hypothesis of Oil producer behaviour", Energy Journal 12(4): 117-138 Crossref

- Darby, M.R.(1982). "the price of Oil and World inflation a Recessions", American Economic Review 72, 738-751.

- Dickey, D.A. and W.A. Fuller (1991). Distribution of the Estimators for Autoregressive Time series with a Unit Root", Journal of the American Statistical Association 74, 427-431 Crossref

- Eastwood, R.K.(1992). "Macroeconomic Impacts of Energy Shocks", Oxford Economic papers 44:403-425 Crossref 
- Eltony, M.N. and M. Al-Awardi (2001). "Oil price fluctuations and their impact on the macroeconomic variables of Kuwait: a case study using a VAR model", international Journal of Energy Research 25(11), 939-959. Crossref

- Farzanegan M.R. and G. Markwardt ( 2009). "the Effects of Oil Price Shocks on the Iranian Economy", Faculty of Business, Dresden University of technology, d-01062, Dresden, Germany. Crossref

- Gordon, Robert J. (1984). "supply shocks and monetary policy revisited". American Economic Review. May 74(2):38-43. Crossref

- Granger, C.W.J. (1969). "Investigating Causal Relations by Econometric Models and crossspectral Methods, Econometrical 37, 424-438. Crossref

- Griffin, J.M. (1985). "OPEC Behaviour: A Test of Alternative Hypotheses", American Economic Review 75, pp.954-963.

- Gounder, R. and M. Bartleet (2007). "Oil Price Shocks and Economic growth: Evidence for New Zealand, 1989-2006" Paper Presented at New Zealand Association of Economist Annual Conference, Christchurch,29th June 2007

- Hamilton, J.D. (1983). "Oil and the Macroeconomy since World War 11, The Journal of Political Economy 91,228-248. Crossref

- Harris, R.I.D.(1995). Using Cointegration Analysis in Econometric Modeling, New York, Prentice Hall.

- International Monetary Fund (IMF) 2005. Oil Market Development and issue", paper prepared by the Policy Development and Review Department. Crossref

- International Monetary FUND (IMF) 2006. International Financial Statistics. Washington, D.C.: IMF.

- Johansen, S. (1991) "Estimation and Hypothesis Testing of Cointegration Vectors in Gaussian Vector Autoregressive Models, Econometrica 59,1551-1580. Crossref

- Johansen, S. (1995). Likelihood-based Inference in Cointegrated Vector Autoregressive Models, Oxford, Oxford University press Crossref

- Jones, C.T.(1991). "OPEC behaviour under falling prices: Implications for Cartel Stability" Energy Journal Vol. 11, No3:117-129 Crossref

- Majidi, M. (2006) "Impact of Oil on international Economy" international Economics paper, Centre for Science and innovation studies, May 2006.

- Mork, K.A. (1994). "Business Cycles and the Oil Market", The Energy Journal, 15 (special issue), the changing world petroleum Market, 39-67. Crossref

- Nnanna, O. J and I. Masha (2003). "Oil price Fluctuation, Macroeconomic behaviour and policy Response in Nigeria: A VAR Specification", West Africa Journal of Monetary and Economic Integration. Vol. 3, No. 1, pp. 85-113.

- Olomol, P.A and A.V. Adejumo (2006). "Oil price Shocks and Macroeconomic Activities in Nigeria". International Research Journal of Finance and Economics Issue 3, pp 28-34

- Osterwald-lenum, M. (1992) "A note with Quantiles of the Asymptotic Distribution of the Maximum likelihood Cointegration rank test statistics", Oxford Bulletin of Economics and statistic 54,481-472. Crossref

- Phillips, P.C.B. and P. Perron (Testing for a Unit Root in Time Series Regression, Biometrika 75,335-346. Crossref

- Raguindin, C.E. and R.G. Reyes (2005). "The effects of oil price shocks on the Philippine school of Economics.

- Rasche, R., and J. Tatom (1981). "Energy price Shocks, Aggregate Supply and Monetary Policy: The Theory and International Evidence", in Brunner, K., and Meltzer, A.H. (Eds). Supply Shocks, Incentives and National Wealth, Carnegie-Rochester conference series on Public policy, 4:9-93. Crossref

- Rotenberg. J.J. and M Woodford ( 1996). "imperfect Competition and the Effects of energy prices", Journal of Money, Credit and Banking, 28,549-577. Crossref

- Statistical Review of World Energy, June 2010, available freely at http://www.bp.com/statisticalreview.

- Tang, W., L, Wu and Z. Zhang (2010). Oil price shocks and their short-and long-term effects on the Chinese economy. Energy Economics, DOI: 10.1016/j.eneco.2010.002. Crossref

- Tobin, J. (1980). "Stabilization Policy Ten Years After", Brookings Papers on Economic Activity 1971. Crossref

- Van Wijenbergin S. (1984). "inflation, Employment, and the Dutch disease in Oil-exporting Countries: A short-run Disequilibrium Analysis, Quarterly Journal of Economics99,233-250. Crossref

- Wakeford J (2006)." The impact of oil price shock on the south African macroeconomy: History and prospects", in Acceleration and shared Growth in South Africa: Determinations, constraints and opportunities. 18-20 October 2006. 
Kanu Success Ikechi, Nwadiubu, Anthony

Global Oil Price Shocks and Effects on Economic Growth: An Econometric Investigation of Nigeria

- Watkins, G.C. (1992)" the Hotelling Principle: Autobahn or Cul de Sac "Energy journal 3(1): 124. Crossref 